E3 Journal of Business Management and Economics Vol. 9(1). pp. 022-029 Jan, 2018

Available online http://www.e3journals.org

ISSN 2141-7482 @ E3 Journals 2018

DOI : http://dx.doi.org/10.18685/EJBME(9)1_EJBME-17-021

Full Length Research Paper

\title{
The impact of CEO' duality and board's size and independence on firms' innovation and financial performance
}

\author{
Nourhene BLIBECH ${ }^{1 *}$ and Sarra Berraies ${ }^{2}$ \\ ${ }^{1}$ FSB, University of Carthage, Tunisia Laboratoire LIFE, University of Manar Tunisia \\ ${ }^{2}$ Université de Tunis, Institut Supérieur de Gestion de Tunis, Laboratoire ARBRE, Tunis, Tunisia
}

Accepted 28 December, 2017

The aim of this article is to highlight the impact of some characteristics of board of directors and CEO' duality on firms' innovation and performance. A series of hypotheses testing the links between the variables was formulated in the basis of a theoretical review. A quantitative research was performed via a questionnaire on a sample of 60 Tunisian listed companies. Moreover, we used a database published by the Stock Exchange of Tunisian Market and the Financial Market Council. Results of the empirical analysis show that innovation positively contributes to firms' financial performance. Findings reveal also that CEO' duality is negatively associated to innovation. This research may represent potential guide for the board of directors in order to improve firms' innovation and firms' financial performance.

Keywords: CEO-duality, innovation, financial performance, board size, independent directors, Tunisia.

\section{INTRODUCTION}

Nowadays, firms' innovation is considered a key element in knowledge economies. The need for innovation has been proven by several studies in the field of management (March, 1991; Porter, 1990). To face the increasingly tough competition and sustain a sustainable competitive advantage, firms are forced to innovate and increase the absorptive capacity of new knowledge (Cohen and Levinthal, 1989).

However, although innovation is a factor of value creation (March, 1991), it is well known that investing in these activities is expensive, risky and leads to conflicts of interest between shareholders and executives.

These conflicts found their origin in differences in terms of risk aversion and planning horizon between the two parties (Byrd et al, 1998). To mitigate these conflicts of interest, various internal mechanisms of corporate governance can be used.

In this research, we address the issue of innovation

\footnotetext{
*Corresponding Author E-mail: blibech_nourhene@yahoo.fr
}

from a financial point of view and we are interested in the internal mechanisms of corporate governance as leverage of innovation and performance of the company.

At this level, to the extent that the commitment to innovative activities is subject most often to conflicts of interest between shareholders and managers, What influence does the board have on the degree of innovation of companies? What influence does it have on the relationship between innovation and the company's performance?

Indeed, the results of earlier studies (Brown and Mahoney 1992, Bantel and Jackson 1989) suggest that a large board has greater potential for disagreement and lack of cohesion. Yermack (1996) and Eisenberg et al (1998) find that the size of the board is negatively correlated with the company's performance. As a result, a limited size of the board seems desirable to ensure strategic decision-making such as the decision to invest in innovative activities in order to improve the performance of the company. Rao and Lee-Sing (1995) and Boone et al (2007) also suggest that a large board is negatively correlated with the degree of innovation. 
As for the presence of external members on the board, most research highlights the relevance and effectiveness of such a presence. The impact of such a structure on the degree of innovation of the company remains mixed. This idea has been confirmed empirically by Dong and Gou (2010) who confirm the positive effect of the presence of independent board directors on $R$ \& $D$ spending. Similarly, Kroll et al (2006) on a sample of US companies, found that the effect of $R$ \& $D$ expenditures on firm performance is positive and significant only at the level of companies with a majority independent directors. on the other hand, the studies by Zahra (1996) Godard (1997b) and Deutsch (2005) find that firms invest more in $R \& D$ activities, the less their board of directors is made up of outside directors. This work supports the idea that internal directors practice future-oriented strategic control and encourage innovation within the firm, while outside directors practice financial control focused on accounting results.

Previous work on the impact of the dual role of CEO and board director on the degree of innovation and performance of companies is mixed. Proponents of duality, such as Godard and Schatt (2000), believe that it is important for the firm to be run by the same person because it avoids miscommunication, decreases the likelihood that actions and expectations the executive and the board of directors are in contradiction. This should therefore facilitate innovation and lead to better performance. However, this idea was not supported by Dutta et al (2004) as well as Jermias (2007) who shows the negative effect of the combination of board and board leadership on the relationship between innovation and performance. of the company.

The remainder of the paper is organized as follow: Section 1 reviews the theoretical background development of hypotheses. Section 2 describes data collection, the research methods and reports the empirical results. and Section 3 concludes the study.

\section{LITERATURE REVIEW}

\section{The effect of board size on innovation and financial performance}

Jensen (1993) considers that a large board is less effective than a small one since it favors the domination and the discretionary power of the director. Previous studies of the relationship between board size and firm performance have produced mixed results. Some studies have found a positive influence of high board size on firm performance (Pearce and Zahra 1992, Dalton et al., 1999). These authors believe that a significant size of the board increases the resources and expertise of the firm (Godard and Chatt, 2004). Others like Yermack (1996) and Eisenberg et al (1998) find that the size of the board is negatively correlated with the company's performance.
Indeed, when the size of the board is reduced, the members more effectively control the director, thus reducing agency conflicts. On the other hand, a large board of directors hardly coordinates the opinions of its members, which accentuates agency conflicts, slows down decision-making and encourages opportunistic behavior by the director (Ginglinger, 2002, Adams and Mehran, 2003). Zona et al; (2013) emphasized that board size positively influences firm innovation. Berraies and Ben Rejeb (2018) found that board size is not associated to firms' innovation. Principe (2017) revealed also that the board size do not contribute to innovation. García-Olalla and García-Ramos (2010) highlighted that the board size improves firm performance. In this line, Linck et al. (2008) stressed that larger boards of directors have the resources and knowledge to contribute to firm performance and agility. However, the benefits of larger board of directors stop when the board reaches a number of members beyond which the communication becomes difficult (Jensen , 1993), which can inhibits creativity and innovation.

As pertinently stated by Conyon and Peck (1998), the influence of board size on corporate performance is mostly negative, thus we hypothesize that:

- $\mathrm{H} 1$ : The board size has a negative effect on firm's financial performance

- H2: The board size has a negative effect on firm's innovation

\section{The effect of the proportion of independent members in the board of directors on the innovation and financial performance}

The independence of directors is probably considered to be the most fundamental dimension of the board and the most studied in literature. A member of the board is independent of the management of the company when he has no relationship of any kind with the company or his group. Governance researchers stipulate that the board of directors is a mean of controlling the actions of the directors whose independence must be guaranteed. In this regard, Weisbach (1988) and Balsmeier et al. (2015) revealed that independent directors are more able to dismiss the manager than non-independent directors. Thus, previous studies (Andres et al, 2005, Lefort and Urzua 2008, Dahya et al, 2008) find that a high proportion of independent external directors on the board increase the company's performance because these directors reduce conflicts of interest and ensure more effective control and management. Fuzi et al. (2016) highlighted that although the firms integrated the highest number of independent directors, it would not guarantee to improve firm performance. Terjesen et al. (2016) found that the external independent directors do not influence the firm performance unless the board of directors is gender 
diversified. Although, Duchin et al. (2011) and Fama and Jensen (1983) found that the independent administrators contribute to firms' performance. Tseng et al; (2013) revealed also that these type of administrators have positive effects on firms' creation value.

Pathan and Faff (2013) revealed that the proportion of independent board members has a negatif effect négatif on firms. Berraies and Ben Rejeb (2016) found on the basis of a study they carried out on the Tunisian listed firms that the independence of board of directors do not influence the firms' exploratory and exploitative innovations. Balsmeier et al. (2014) suggested that the independent administrators contribute to strategic R\&D and innovation. Chen et al. (2016) show that the technology diversity strategy positively moderates the link between the proportion of independent board members and innovation performance, whereas the absorptive capacity negatively moderates this latter link, thus we hypothesize that:

- H3: The proportion of independent members of board of directors has a positive effect on firm's financial performance

- H4: The proportion of independent members of board of directors has a positive effect on firm's innovation

\section{The effect of the CEO' duality on innovation and financial performance}

The debate over the effects of the duality of the functions of Chief Executive Officer and Chairman of the Board (duality) on the company's performance is unresolved. Thus, some studies conclude that duality allows for better performance (Cannella and Lubatkin 1993, Sridharan and Marsinko 1997). Some autors believe that it is important that the firm is managed by the same person because it avoids miscommunication, offers more flexibility to seize new opportunities and lead to better performance. Moreover, in France, Godard and Schatt (2000) find that companies that have opted for duality of the functions are more profitable in the long term. Other studies indicate that companies adopting the separation of the two functions of general manager and chairman of the board perform better than the one combining these two functions (Berg and Smith 1978; Boyd 1995; Pi and Timme, 1993). The argument put forward is that the combination of functions decreases the effectiveness of the board of directors and increases the risk of opportunistic actions by the manager who takes the position of judge and party.

The theoretical debate on the choice between cumulation and separation of functions has put forward two contrary points of view as to the desirability of one or other of the two regimes. A major part of studies recommends the separation of functions, the argument put forward is that this separation allows the control of directors' decisions and diminishes agency conflicts (Fama and Jensen 1983; Pi and Timme, 1993; Jensen 1993). Indeed, directors can easily defend the projects they have initiated and implemented even if they do not create shareholder value. This has been confirmed by the study by Jermias (2007) which shows the negative effect of the combination of the duality of the functions of Chief Executive Officer and Chairman of the Board on the relationship between the innovation effort and the company's performance. Principe (2017) found that the CEO-duality do not contribute to the innovative activity, thus we hypothesize that:

- H5: The CEO' duality has a negative effect on firm's financial performance

- H6: The CEO' duality has a negative effect on firm's innovation

\section{The effect of innovation on financial performance}

A multitude of studies outlined the role of innovation in improving firms' performance (Berraies et Hamouda, 2018; Berraies et al., 2014; Nonaka and Takeuchi, 1995; Uzkurt et al, 2013). The identification of new ideas or the creation of new products or services are associated with firms' performance (Nonaka and Takeuchi, 1995; Uzkurt et al, 2013). Sok and O-Cass (2015) revealed that innovation enhance the service quality and improves in turn the firms' financial performance. Ho et al. (2017) found that there is a positive link between innovation and financial performance. By innovating, firms are likely to better respond to the environment changes and to the varying needs of customers, who in turn are incited to byu the product or the service of the firms and to be satisfied and loyal. However, Gok and Peker (2016) suggested that there is a negative relationship between innovation and financial performance, thus, we hypothesize that:

- H7: The innovation has a positive effect on firm's financial performance

\section{EMPIRICAL STUDY}

\section{Data collection and variable measurement}

A quantitative study was carried out on 75 Tunisian listed companies. We collected data through two means. Indeed, for the firms' innovation and financial performance, we used a questionnaire integrating scale of measurement of innovation and financial performance. This questionnaire was administrated to senior managers of each company. Out of the 75 companies surveyed, 60 valid questionnaires were obtained, which account a response rate of $80 \%$. The responses concerning each company were matched to the corresponding data related to the proportion of independent members of 
Table 1. Descriptive statistics

\begin{tabular}{lllll}
\hline Constructs & Mean & SD & Skewness & Kurtosis \\
\hline Board size & 9,37 & 2,428 &,- 475 &,- 585 \\
Independent members of BD &, 47 &, 853 & 1,463 &, 540 \\
Duality &, 33 &, 475 &, 725 & $-1,526$ \\
Innovation & 3,6556 & 1,13158 &,- 269 & $-1,357$ \\
Performance & 3,4056 & 1,02711 &, 156 & $-1,088$ \\
Firm size & 719,52 & 1569,658 & 3,567 & 14,346 \\
Firm age & 24,98 & 28,655 & 1,364 & 1,962 \\
\hline
\end{tabular}

Table 2. Dimensionality and reliability of scales of measurement of innovation and financial performance

\begin{tabular}{llll}
\hline Variables & $\begin{array}{l}\text { Number } \\
\text { of items }\end{array}$ & $\begin{array}{l}\text { Cronbach's } \\
\text { Alpha }\end{array}$ & $\begin{array}{l}\text { Percentage of } \\
\text { explained variance }\end{array}$ \\
\hline Innovation & 3 & 0.961 & $92.935 \%$ \\
Financial performance & 3 & 0.983 & $96.677 \%$ \\
\hline
\end{tabular}

board of directors, the CEO' duality, the board size, the firm age and the firm size. These data were collected via a database published by the Stock Exchange of Tunisian Market and the Financial Market Council.

The independent BD was measured by the proportion of independent directors in the boardroom. The innovation was measured by 5 items developed by Svetina and Prodan (2009). This scale of measure integrates a Likert scale of 5 points (1 means strongly disagree to strongly agree). The financial performance is conceptualized through 7 items in the line of Balanced Scorecard (BSC) methodology (Kaplan and Norton, 1992). The scale of measurement of financial performance incorporated items related to return on assets, return on investment, sales' growth, firm's net profit margin, return on sales, return on equity and market share growth. These 7 items are based on a Likert scale of 5-point ranging from 1 "much lower" to 5 "much higher". Duality is measured by a dummy variable where 1 means that the CEO and the board chair are the same person in a company and 0 otherwise (Rutledge, 2016). Moreover, board size is operazionalized as "the total number of full-time directors with voting rights on the board" (Gabrielsson, 2007, p 522).

In the research model, we have added two control variables namely the age of the company and the size of the company. Indeed, these two variables are likely to affect firms' innovation (Hansen, 1992; Yu and Lee, 2017). The age of the company is operazionalized through the number of years since the creation of the company. The size of the company is measured through the logarithm of the total number of employees.
Table 1 outlines the means and standards deviation of all constructs and shows in the line of the values of Skewness and Kurtosis that there is no normality problem.

\section{Dimensionality and reliability of constructs}

The collected data for the two variables-innovation and financial performance- were performed by an exploratory analysis via the software SPSS software 21. First, a principal component analysis was used to test dimensionality of these variables' scales. In this line, a Varimax rotation was processed. We suppressed items with low factor communalities. Then, we analyze the Cronbach alpha to test the constructs' reliability. For the two scales measuring respectively innovation and financial performance, the values of Cronbach alpha meet the rule of thumb of 0.7 recommended by Nunnally (1978) (Table 2). The percentage of explained variance exceeds $60 \%$ for the two constructs. The final structure of ach construct is presented in Table 2 .

\section{Correlation analysis}

Table 3 points out the results of Pearson's correlations between constructs. This table shows that there is no problem of multicolinearity as there is no coefficient of correlation between independent variables which exceeds 0.7 . 
Table 3: Correlations between variables

\begin{tabular}{llllllll}
\hline Variable & BD Size & INDEP & DUAL & Firm Size & Firm Age & PERF & INNOV \\
\hline BD Size & 1 & & & & & & \\
INDEP &, $403^{* *}$ & 1 & & & & & \\
DUAL &,- 005 &, 218 & 1 & & & & \\
Firm Size &, 155 &, 097 &, $313^{*}$ & 1 & & & \\
Firm Age &, $324^{*}$ &, 258 &, 182 &, $445^{* *}$ & 1 & & \\
PERF &, 005 &,- 146 &,- 172 &, 254 &, 039 & 1 & \\
INNOV &,- 085 &,- 122 &,$- 267^{*}$ &, 003 &,- 135 &, $495^{* *}$ & 1 \\
\hline
\end{tabular}

${ }^{*} p<0.10,{ }^{* *} p<0.05,{ }^{* * *} p<0.001 ; N=34$

Table 4: Results of the first model's regression

\begin{tabular}{lllll}
\hline Hypotheses & Variables & Beta & t & P value \\
\hline H7 & (Constant) & & 2.662 & 0.010 \\
H1 & Innovation & 0.464 & 3.974 & 0.000 \\
H3 & Board Size &,- 025 & 0.194 & 0.847 \\
H5 & Duality &,- 119 & $-0,952$ &, 345 \\
& Independent boards &,- 068 &,- 529 &, 599 \\
& Firm Age & 0.003 & 0.026 & 0.979 \\
& Firm Size & 0.291 & 2.204 & 0.032 \\
\hline
\end{tabular}

$\mathrm{R}^{2}: 0.328$

$\mathrm{F}: 4.303^{* *}$

Dependent variable : Financial performance

\section{Model Specification and regression analysis}

Model (1) is expressed in Equation 1 and is performed to analyze the impact of Board size, the proportion of independent members of $\mathrm{BD}$, the duality of CEO and the innovation on firm's financial performance. Model (2) is expressed in Equation 2 and is used to study the effect of Board size, the proportion of independent members of $\mathrm{BD}$, the duality of CEO on the innovation. These models also integrate two control variables that have been highlighted in previous research as predictor of firms' financial performance and innovation, namely firm size and firm age (Hansen, 1992; Yu and Lee, 2017).

$P F=\beta 0+\beta 1 B S i+\beta 2 I D i+\beta 3 D U A L i+\beta 4 I N N O V+\beta 5 F S I Z E i$ $+\beta 9 F A G E i+\varepsilon i$

INNOV $=\alpha 0+\alpha 1 B S i+\alpha 2 I D i+\alpha 3 D U A L i+\alpha 4$ FSIZEi $+\alpha 5$

FAGEi $+\varepsilon i$

Where:

- The dependent variable is PF = Financial Performance

- The independent variables integrate BS: the board size as the number of administrators on the boards; ID = the proportion of independent directors on the boardroom; DUAL = the CEO duality

- The control variables include FSIZE = Firm size measured by the logarithm of the total number of employees and the FAGE=Firm age as the number of years since the creation of the company.

A multiple regression analysis was performed via SPSS 21.0 (Table 4 and 5). First, table 4 highlights the results for the first model tested. The R square is equal to 0.328 and the test of Fisher is significant $\left(4.303^{* *}\right)$. In this line, findings indicate that innovation is positively associated with financial performance $(\beta=0.464, p<0.001)$. These findings corroborate the research of Berraies and Hammouda (2018) and Berraies et al. (2014). Therefore, Hypothesis 7 is confirmed. The data analysis showed also that CEO' duality, the proportion of independent directors on board and the board size are not significantly correlated to firms' financial performance. Our result is not consistent with. Henceforth, hypotheses 1, 3 and 5 are rejected. As for control variables, the firm size has a positive and significant effect on financial performance $(\beta$ $=0.291, p<0.05)$. The firm age is not associated to financial performance.

Moreover, table 5 point out the findings for the second model tested. The $R$ square is equal to 0.124 and the test of Fisher is significant $\left(2.025^{\star}\right)$. Results outline that the CEO' duality is negatively associated with innovation. Hypothesis 4 is thus confirmed. These results support the work of Jermias (2007). Then, findings reveal that the proportion of independent directors on board and the board size are not significantly correlated to innovation. 
Table 5: Results of the second model's regression

\begin{tabular}{lllll}
\hline Hypotheses & Variables & Beta & $\mathbf{t}$ & P value \\
\hline & (Constant) & & 1,976 &, 042 \\
H2 & Board Size &, 035 &, 231 &, 819 \\
H4 & Duality & $-0,298$ & $-2,231$ & 0,021 \\
H6 & Independent boards &,- 051 &,- 343 & 0,733 \\
& Firm Age &,- 136 &,- 884 &,- 381 \\
& Firm Size &, 138 & 0.902 & 0.371 \\
\hline
\end{tabular}

$\mathrm{R}^{2}: 0.124$

$F: 2.025^{*}$

Dependent variable : innovation

Hypotheses 2 and 6 are thus rejected. This finding is consistent with Berraies and Ben Rejeb (2018).

\section{Discussion and conclusion}

This research aimed to analyze the role played by some characteristics and composition of board of directors, namely the board size, the proportion of independent variable on the board and the CEO' duality on firms' innovation and financial performance of Tunisian listed companies. On the basis of a theoretical review, we developed a series of hypotheses which point out the links between the central variables of our study. These hypotheses were tested on a sample of 60 Tunisian listed companies.

Our results show that the board size does not contribute to both innovation and financial performance. Most of the board directors of surveyed companies are mediumsized. These findings are in line with those of Jensen (1993) who stressed that the more the number of members of Board of directors is larger, the more the communication is likely to be difficult. Moreover, besides the size of the board, it will be interesting to study its composition in terms of gender diversity, skills profile, age diversity, culture diversity...These variables could better inform us about the effectiveness of the board and the synergy or conflicts that could result from this composition. Larger boards of directors are not necessarily more efficient (Principe, 2017).

In addition, regarding the effect of the independent directors on the firms' innovation and performance, the findings have infirmed this link. A possible explanation is provided by Hermalin and Weisbach (1991), Berraies and Ben Rejeb (2018) and Principe (2017) who outlined that the independent administrators are rather unable to decipher the complexity of the company's activities and may be unsuccessful in controlling the managers and representing shareholders' interests properly. This evidence contradicts the results of Balsmeier et al. (2015) who pointed out that independent directors have a fundamental role of monitoring. Thus, the independent directors should familiarized with the companies', strategies, resources and activities and better monitored to bring positive shareholders values and synergy.

Furthermore, the CEO' duality does not contribute significantly to financial performance but is negatively associated to firms' innovation of Tunisian listed companies. This result was well confirmed by the study by Jermias (2007) which shows the negative effect of the combination of management and board chairmanship functions on the relationship between the innovation effort and the performance of the company. The combination of functions favors a climate conducive to the development of opportunistic and inefficient behavior on the part of the manager, which will have adverse consequences for shareholders' wealth.

Moreover, we found that firms' age has no effects on innovation and financial performance, while this latter variable is associated to firms' size. Indeed, large firms have the ability the resources needed for innovation (Vaona and Pianta, 2008).

Finally, our work pointed out that innovation is a lever for financial performance. Exploring new opportunities and creating new products and services allows firms to satisfy the customers' needs, which push them to buy and thus to improve the financial performance.

This research has theoretical and practical contributions. Our study adds to the existing literature that has analyzed the link between boards' composition and characteristics and firms' financial performance and innovation. In addition, this research offers a grid for boards' members to improve their monitoring effectiveness, which in turn can boosts innovation and financial performance. In particular, our results outline that the board should not be too large to permit the directors to exchange knowledge and communicate effectively, to generate new ideas and initiate innovation's activities. Also, the firms should better monitor the independent directors and give them all the information they required and thus permit him to benefit the board from their networks, knowledge and expertise.

This work contains some limitations. First, the sample was limited to 60 Tunisian Listed companies. In continuity of this research, authors may extend the field of this study to other firms and countries. The relative reduced 
size of the sample limit the generalizability of the results. Moreover, future studies may benefit from integrating other variables that can enrich the model such as age diversity and gender diversity.

\section{References}

Aboody D, Lev B (2000). «Information asymmetry, R\&D and insider gains", J. Financ. 55(6): 2747-2766.

Adams \& Mehran (2003). "Corporate Performance, Board Structure, and their Determinants in the Banking Industry ", Federal Reserve Bank of New York Staff Reports, n`330.

Andres P, Azofra V, Lopez F (2005). "Corporate boards in OECD countries: size, composition, functioning and effectiveness", Corporate Governance: An Intl. Rev. 13(2): 197-210.

Balsmeier B, Buchwald A, Stiebale J (2014). "Outside directors on the board and innovative firm performance", Res. Pol. 43(10): 18001815.

Bantel K, Jackson S (1989). «Top management and innovations in banking: does the composition of the top team make a difference", Strateg. Manage. J. 10(1): 107-124.

Berg SV, Smith SK (1978). "CEO and board chairman: A quantitative study of dual vs unitary board leadership», Directors \& Boards, 3(1): 34-39.

Berraies S, Ben HM (2018). "Effect of customer empowerment on firms' financial performance: Mediating role of innovation and customer satisfaction», International J. Bank Marketing, (In press)

Berraies S, Ben RW (2018). «Role and size of Board direction: What effects on exploitative innovation and exploratory innovation: the case of listed Tunisian firms", Intl. J. Entrep. Innovation Manage. (In press).

Berraies S, Chaher M, Ben YK (2014). «Employee empowerment and its importance for trust, innovation and organizational performance", Bus. Manage. Strateg. 5(2): 82-103

Boone AL, Fied LC, Karpoff JM, Raheja CG (2007). «The determinants of corporate board size and composition: An empirical analysis", J. Financial. Econ. 85(1): 66-101.

Boyd BK (1995). "CEO duality and firm performance: A contingency model», Strateg. Manage. J. 16(4): 301-312.

Brown W, Mahoney M (1992) «Acquisition performance and corporate board composition», Working paper, Clemson University.

Byrd J, Parrino R, Prjtsch G (1998), "Stockholder-manager conflicts and firm value", Financial Analysts J. 54(3): 14-30.

Chen CJ, Lin BW, Lin YH, Hsiao YC (2016). "Ownership structure, independent board members and innovation performance: A contingency perspective », J. Bus. Res. 69: 3371-3379.

Cohen WM, Levinthal DA (1989), «Innovation and Learning: The two faces of R\&D», The Econ. J. 99(397): 569-596.

Dahya J, Dimitrov O, McConnell JJ (2008). «Dominant shareholders, corporate boards, and corporate value: A cross-country analysis», J. Financial. Econ. 87(1): 73-100.

Dalton DR, Daily CM, Ellstrand AE, Johsnson JL (1998). «Meta-analysis reviews of board composition, leadership structure and firm performance», Strateg. Manage. J. 19(3): 269-290.

Deutsch Y (2005). "The impact of board composition on firms' critical decisions: A metaanalysis review», J. Manage. 31(3): 424-444.

Ding Y, Stolowy H, Tenenhaus M (2007). «R\&D productivity: An international study», Rev. Accounting. Financ. 6(1): 86-101.

Dong J, Gou YN (2010). « Corporate governance structure, managerial discretion and the R\&D investment in China", International Rev. Econ. Financ. 19(2): 180-188.

Dutta S, Kumar U, Kumar D, Zhu P (2004). «Determinants of corporate R\&D intensity: Canadian evidence", 32nd Annual Administrative Sciences Association of Canada Conference, ASAC Quebec, 2004.

Eisenberg T, Sundgren S, Wells MT (1998). «Larger board size and decreasing value in small firms", J. Financial. Econ. 48(1): 35-54.

Fama EF, Jensen MC (1983 a), «Separation of ownership and control», J. Law. Econ. 26(2): 301-325.
García-Olalla M, García-Ramos R (2010). « Family ownership, structure and board of directors effectiveness: Empirical evidence from European firms", In 9th Annual IFERA Conference, Lancaster, United Kingdom.

Garner J, Yul T, Kim WY (2017). "Boards of directors : a literature review », Managerial Financ. 43(10) : 1189-1198.

Ginglinger E (2002). «L'actionnaire comme contrôleur », Revue Française de Gestion, 141: 37-55.

Godard L (1997b). "Conseil d'administration, système de contrôle et d'incitation des dirigeants et stratégie de la firme", In le gouvernement des entreprises, Charreaux, 1997, Economica, pp. 211-239.

Godard L, Schatt A (2000). «Faut-il séparer les fonctions de décision et de contrôle?», Congrès de l'A.F.F.I., Paris (juin 2000) et Journées des I.A.E, Biarritz (septembre 2000).

Godard L, Schatt A (2005a) «Les déterminants de la qualité des conseils d'administration français», Cahier de recherche du FARGO, $\mathrm{n}^{\circ} 1040603$.

Gun JY, Joonkyum L (2017). «When should a firm collaborate with research organizations for innovation performance? The moderating role of innovation orientation, size, and age », The J. Technol. Transfer. 42(6): 1451-1465;

Jensen MC (1993). "The modern industrial revolution, exit, and the failure of internal control systems.", The J. Financ. 48(3): 831-880.

Jensen MC (1993). "The modern industrial revolution, exit and the failure of internal control systems», J. Financ. 48(3): 831-881.

Jermias $J$ (2007). "The effects of corporate governance on the relationship between innovative efforts and performance", Eur. Accounting. Rev. 16(4): 827- 854.

John AH (1992). "Innovation, firm size, and firm age», Small Bus. Econ. 4(1): 37-44.

Khanh L, PhiHo C, NgocNguyen RA (2017). « Exploring market orientation, innovation, and financial performance in agricultural value chains in emerging economies », J. Innovation. Knowledge. L(June): 12.

Kroll M, Walters B, Le SA (2006). "The moderating effects of external monitors on the relationship between $R \& D$ spending and firm performance», J. Bus. Res. 59(2): 278-287.

Lefort F, Urzua F (2008). «Board independence, firm performance and ownership concentration: Evidence from Chile», J. Bus. Res. 61(6): 615- 622 .

Linck JS, Netter JM, Yang T (2008). «The determinants of board structure», J. Financial. Econ. 87(2): 308-328.

Lööf $H$, Heshmati $A(2006)$. "On the relationship between innovation and performance: A sensitivity analysis", Econ. Innovation. New. Technol. 15(5-6): 317-344

Martin JC, Simon IP (2010). " Board size and corporate performance: evidence from European countries », The Eur. J. Financ. 4: 291-304.

Nonaka I, Takeuchi H (1995). "The Knowledge-creating Company", New York: Oxford University Press.

Nunnally J, Bernstein I (1994). "Psychometric Theory", New York: McGraw Hill.

Pathan S, Faff R (2013). "Does Board Structure in Banks Really Affect their Performance?”, J. Banking. Finance. 37(5): 1573-1589.

Pearce JA-II, Zahra SA (1989), «Board of directors and corporate financial performance:A review and integrative model», J. Manage. 15(2): 291-334.

Pearce JA, Zahra SA (1992). "Board composition from a strategic contingency perspective", J. Manage. Studies. 29(4): 411-438.

Pi L, Timme SG (1993). "Corporate control and bank efficiency», J. Banking. Financ. 17(2-3): 515-530.

Porter ME (1992). "Capital disadvantage: American's failing capital investment system», Harvard Bus. Rev. 70(5): 65-85.

Prencipe A (2016). «Board Composition and Innovation in University Spin-offs. Evidence from the Italian Context », J. Technol. Manage. Innovation. 11(3): 33-39.

Rao PS, Lee-Sing CR (1995). "Les structures de régie, la prise de décision et le rendement des firmes en Amérique de nord», Finance, Economie et Comptabilité, 5: 27-45. 
Schamberger DK, Cleven NJ, Brettel M (2013). "Performance Effects of Exploratory and Exploitative Innovation Strategies and the Moderating Role of External Innovation", Partners Industry and Innovation. 20(4): 336-356.

Sharifah FSF, Syahrina AAH, Julizaerma MK (2015). «Board ndependance and Firm Performance », Procedia Econ. Financ. 37: 460-465.

Sougiannis T (1994). "The accounting based valuation of corporate R\&D», The Accounting Rev. 69(1): 44-68.

Svetina A, Prodan I (2008). "How Internal and External Sources of Knowledge Contribute to Firms' Innovation Performance", Managing Global Transitions. 6(3): 277-299. Phyra S, Aron O'C (2015) "Achieving service quality through service innovation exploration - exploitation: the critical role of employee empowerment and slack resources", J. Services Marketing, 29(2): $137-149$

Terjesen S, Couto E (2015). "Does the Pesence of Independent and Female Directors impact Firm Performance? A Mlticountry Study of Board », J. Manage. Govern. 20(3): 447-483.
Uzkurt C, Kumar R, Kimzan HS, Eminoğlu G (2013). "Role of Innovation in the Relationship between Organizational Culture and Firm Performance: A Study of the Banking Sector in Turkey", European J. Innovation Manage. 16(1): 92-117.

Weisbach M (1988). "Outside Directors and CEO turnover», J. Financ. Econ. 20(1-2): 431-460.

Yermack D (1996). «Higher market valuation of companies with small board of directors», J. Financial. Econ. 40(2): 185-211.

Zahra SA (1996). "Governance, ownership and corporate entrepreneurship: the moderating impact of industry technological opportunities", Acad. Manage. J. 39(6): 1713-1735.

Zona F, Zattoni A, Minichilli A (2013). «A contingency model of boards of directors and firm innovation: The moderating role of firm size», British J. Manage. 24(3): 299-315. 